\title{
Soil microbial properties under different vegetation types on Mountain Han
}

\author{
WANG Miao ${ }^{1,2}$, QU LaiYe ${ }^{1 *}$, MA KeMing ${ }^{1} \&$ YUAN Xiu ${ }^{1}$ \\ ${ }^{1}$ State Key Laboratory of Urban and Regional Ecology, Research Center for Eco-environmental Science, Chinese Academy of Sciences, \\ Beijing 100085, China; \\ ${ }^{2}$ University of Chinese Academy of Sciences, Beijing 100039, China
}

Received March 5, 2013; accepted April 16, 2013

\begin{abstract}
This study investigated the influence of broadleaf and conifer vegetation on soil microbial communities in a distinct vertical distribution belt in Northeast China. Soil samples were taken at 0-5, 5-10 and 10-20 cm depths from four vegetation types at different altitudes, which were characterized by poplar (Populus davidiana) (1250-1300 m), poplar (P. davidiana) mixed with birch (Betula platyphylla) (1370-1550 m), birch (B. platyphylla) $(1550-1720 \mathrm{~m})$, and larch (Larix principis-rupprechtii) $(1840-1890 \mathrm{~m})$. Microbial biomass and community structure were determined using the fumigation-extraction method and phospholipid fatty acid (PLFA) analysis, and soil fungal community level physiological profiles (CLPP) were characterized using Biolog FF Microplates. It was found that soil properties, especially soil organic carbon and water content, contributed significantly to the variations in soil microbes. With increasing soil depth, the soil microbial biomass, fungal biomass, and fungal catabolic ability diminished; however, the ratio of fungi to bacteria increased. The fungal ratio was higher under larch forests compared to that under poplar, birch, and their mixed forests, although the soil microbial biomass was lower. The direct contribution of vegetation types to the soil microbial community variation was $12 \%$. If the indirect contribution through soil organic carbon was included, variations in the vegetation type had substantial influences on soil microbial composition and diversity.
\end{abstract}

vegetation types, soil organic carbon, soil microbial composition, fungal catabolic diversity

Citation: Wang M, Qu L Y, Ma K M, et al. Soil microbial properties under different vegetation types on Mountain Han. Sci China Life Sci, 2013, 56: 561-570, doi: 10.1007/s11427-013-4486-0

The microbial community mediates decomposition processes, regulates nutrient cycling, and influences soil functional diversity, and it potentially represents a mechanistic link between plant and ecosystem functions [1,2]. Currently, there is considerable interest in understanding the driving forces of the relationship between the soil microbial community and plant community [3]. The effects of aboveground plants on microbial parameters, including microbial community structure and function, i.e., catabolic capacity, have been studied $[2,4,5]$. However, the results of the stud-

*Corresponding author (email: lyqu@ rcees.ac.cn) ies are insufficient. Some studies [2,6] found a significant effect of plant diversity on soil microbial biomass and community structure while others did not find any discernible effect of plant diversity on these microbial properties $[4,5]$. Since plants have broad variations in their natural history and physiology [7], it is likely that differences in plant species create distinctive soil environments and biotic communities [8]. For example, broadleaf and conifer vegetation differ in their biochemical composition. Changes in plant species could alter the production and the composition of organic compounds in detritus, and thus alter the composition and function of heterotrophic microbial communities [2,9]. 
Previous studies suggest that the differences in heterotrophic microbial community structure and function in forest soil are mainly linked with the quality of soil organic matter [10-12]. The usability and biochemical composition of litterfall from dominant species affect soil organic matter to a large extent $[13,14]$. Zak et al. [15] indicated that microbial biomass and labile organic matter pools changed predictably across broad gradients of aboveground net primary production (NPP), supporting the idea that microbial growth in soil was constrained by $\mathrm{C}$ availability. Vegetation community composition, which is influenced by environmental forces, influence soil organisms in underground communities through litterfall and exudates [16]. Furthermore, biotic and environmental forces, which drive the activity, structure, and diversity of soil microbial communities, are controlled by many factors including plant species [17] and edaphic conditions [18,19]. Staddon et al. [20] studied the differences in soil microbes along a climate gradient, and suggested that microbial community structure [21] and catabolic diversity [22] were related to the change in temperature and moisture along the altitudinal gradient. Factors which represent nutrition utility such as $\mathrm{C} / \mathrm{N}$ ratio [19] and available nitrogen [12], are regarded as the main determinants of soil microbial community structure. White et al. [23] maintained that $\mathrm{pH}$ was the most important factor impacting soil microbial community function in coniferous forests. There is a strong relationship between $\mathrm{pH}$ and abundance of soil PLFAs [18,24,25]. The coherent variability of vegetation, soil organic matter, and microbial community can be linked with $\mathrm{pH}[12,18,24-26]$. The nutrient turnover rate in broadleaf forests is faster than that in conifer forests, which leads to high contents of soil nutrients in broadleaf forests [27]. Bacteria prefer high-nutrient soil; conversely, fungi prefer relatively infertile soil. Fungi are the major decomposers in the boreal system, and they adapt to infertile soil with low $\mathrm{pH}$ and difficult-to-decompose substrates [28]. There are, however, no definite conclusions on the decisive elements of variability in soil microbial community structure and the role of fungi in the shift of vegetation from deciduous to coniferous.

This study selected a distinct belt on Mount Han, where the dominant tree species changed from broadleaf to conifer, to study the influence of vegetation types on soil microbial biomass and compositions. Poplar (Populus davidiana) (P), birch (Betula platyphylla) (B) and larch (Larix principisrupprechtii) (L) are the dominant tree species in the forests of Northeast China, the main wood production region of China. On Mt. Han the effects of these different dominant tree species on soil microbial community was investigated by analyzing the differences between the broadleaf, mixed broadleaf, and conifer soils at three depths with special focus on the fungal characteristics of each soil, such as catabolic diversity. The primary questions addressed were (i) is the soil microbial community affected by the vegetation type or the soil properties to a larger extent as the vegetation varied from broadleaf forests to conifer forests? (ii) Would the biomass and catabolic diversity of fungi response consistently to the variation of vegetation types?

\section{Materials and methods}

\subsection{Site description}

The study area was on Mt. Han (1950 m), the second highest mountain of the SaiHanWuLa National Nature Reserve $\left(43^{\circ} 59^{\prime}-44^{\circ} 27^{\prime} \mathrm{N}, 118^{\circ} 18^{\prime}-118^{\circ} 55^{\prime} \mathrm{E}\right)$. The annual average temperature and precipitation was $2^{\circ} \mathrm{C}$ and $400 \mathrm{~mm}$, respectively. July was the hottest month with the temperatures reaching $29^{\circ} \mathrm{C}$, and the average precipitation in summer was $\sim 300 \mathrm{~mm}$ which accounts for $70 \%-80 \%$ of annual precipitation. There was a distinct vertical distribution of vegetation types along the shady slope of Mt. Han. The lowest elevations were dominated by poplar (Populus davidiana) (1250-1300 m), followed by birch (Betula platyphylla) and poplar mixed forest (BP) (1370-1550 m), then birch $(B$. platyphylla) (1550-1720 m), and finally larch (Larix principis-rupprechtii) (1840-1890 m) at the highest elevations. Poplar usually forms patches among birch forest. Birch was the largest forest vegetation in the nature reserve and the main tree species apart from poplar, birch and larch were Tilia mongolica, Quercus mongolica, Acer mono and Sorbus pohuashanesis Hedl. Among the shrubs on the forest floor, Ostryopsis davidiana was the most widespread broad-leaved species, found at the base of birch. In elevations above the Ostryopsis davidiana shrub, small areas of Rhododendron dahuricum shrubs were distributed on the deteriorated forest sites. Shrubby vegetation was distributed extensively in this area, ranking second only to the tree vegetation. The soil under the broadleaved deciduous forests was typical brown soil, while grey wooded soil was distributed under mixed broadleaf-conifer forests. Black soil was under subalpine meadow on the top of the mountain.

\subsection{Soil sampling}

Soil sampling was performed in August 2010. For each vegetation type, three replicate plots were randomly selected. Each plot was $\sim 20 \mathrm{~m} \times 20 \mathrm{~m}$. Soil samples were collected from three depths $(0-5,5-10$ and $10-20 \mathrm{~cm})$ under the dominant tree species in each plot with a soil auger $(5 \mathrm{~cm}$ in diameter). The soil was sieved to $2 \mathrm{~mm}$ and split into three subsamples. The sample for soil microbe measurement was removed of all visible roots and stored at $4^{\circ} \mathrm{C}$. The sample used for phospholipid fatty acid (PLFA) measurement was stored at $-80^{\circ} \mathrm{C}$ and the remaining soil was used for soil property measurement after air drying. Soil chemical and physical properties are listed in Table 1 . 
Table 1 Soil chemical and physical properties (mean value \pm standard deviation) ${ }^{\text {a) }}$

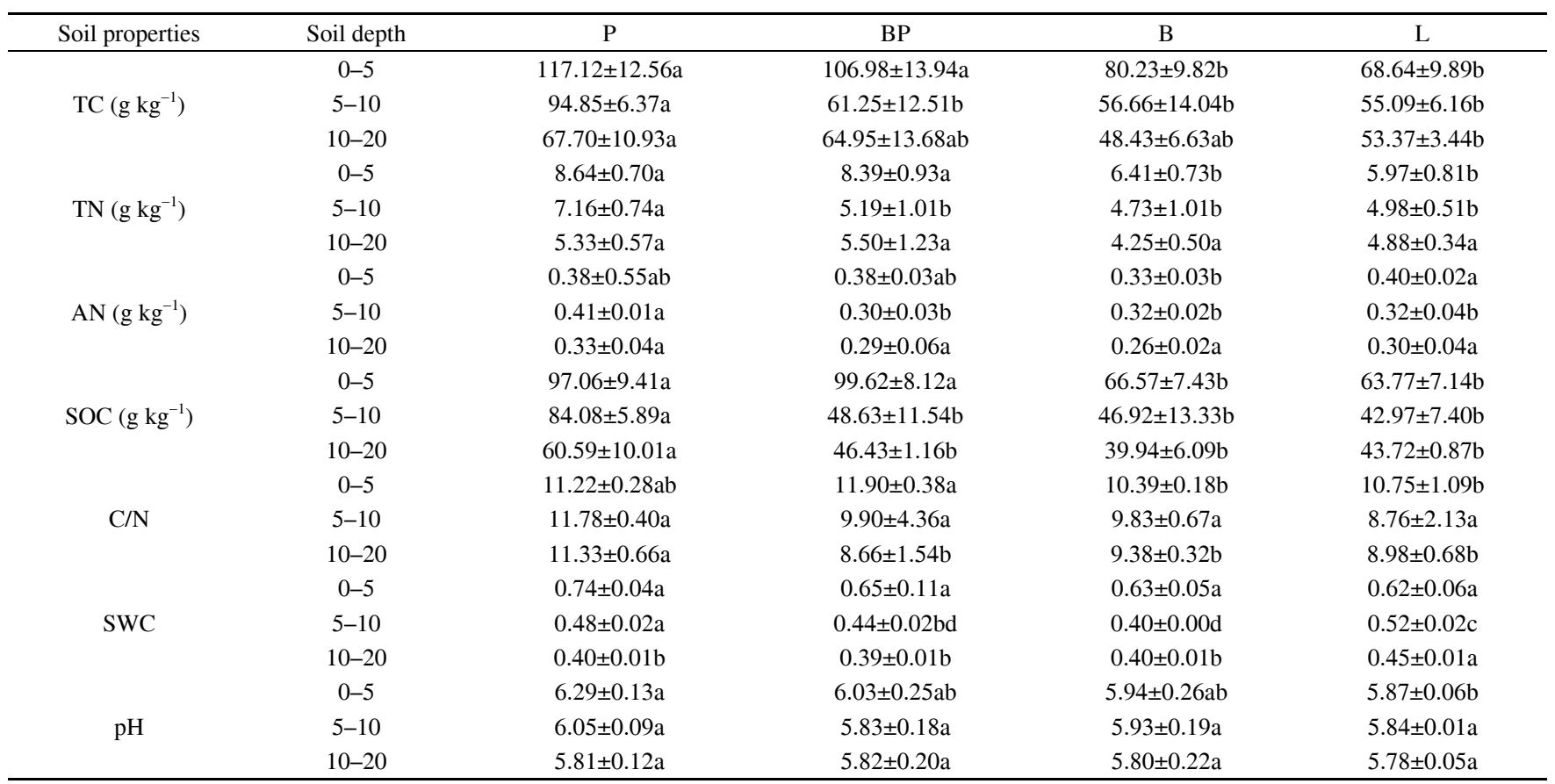

a) P, poplar; BP, Betula and poplar mixed forest; B, birch; L, larch; SOC, soil organic carbon; TC, total carbon; TN, total nitrogen; SWC, soil water content; AN, available nitrogen; C/N, SOC/TN.

\subsection{Soil microbial composition and catabolic diversity analysis}

Soil microbial biomass $\mathrm{C}$ (MBC) and microbial biomass $\mathrm{N}$ $(\mathrm{MBN})$ were measured using the fumigation-extraction method [29] and estimated based on the differences in total organic $\mathrm{C}$ and $\mathrm{N}$ between the fumigated and un-fumigated soil samples. Total organic $\mathrm{C}$ was measured with a fullyautomatic UV-Persuate TOC analyzer (Tekmar-Dohrmann Co. USA) using a Kc factor of 0.45 [30]; total organic $\mathrm{N}$ was measured by $\mathrm{K}_{2} \mathrm{~S}_{2} \mathrm{O}_{4}$ digestion-UV spectrophotometry (GB 11894-89) using a $\mathrm{K}_{\mathrm{N}}$ factor of 0.54 [31].

Soil microbial community structure was determined by analyzing PLFA composition. PLFAs were extracted and analyzed using a procedure described by Bligh and Dyer [32] and Frostegård et al. [33]. The lipids were extracted and then identified and quantified by chromatographic retention time and mass spectral comparison using an Agilent 6890N GC with an Agilent 5975C mass selective detector. The peaks were identified using a standard qualitative bacterial acid methyl ester mix (Sigma Aldrich, Canada) that ranged from $\mathrm{C} 11$ to $\mathrm{C} 20$. For each sample, the abundance of individual fatty acid methyl-esters was expressed in nmol PLFA $\mathrm{g}^{-1}$ dry soil. The fatty acid nomenclature used was that described by Frostegård et al. [34]. The sum of the following PLFAs was used as a measure of the bacterial biomass: i14:0, i15:0, a15:0, 15:0, i15:1, 16:0, i16:0, i16:1, $16: 1 \omega 7,16: 1 \omega 5 \mathrm{c}$, i17:0, a17:0, cy17:0, 17:0, 17:1 $\omega 8 \mathrm{c}$,

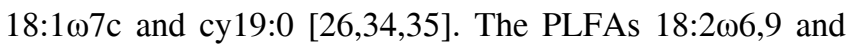

18:1 $\omega 9$ were used as a measure of fungal biomass [26,36].

Soil fungal community level physiological profiles (CLPPs) were constructed using Biolog FF Microplates and the Biolog full-automatic microbial identification and analysis system [37]. A mass of fresh soil equivalent to $10 \mathrm{~g}$ of dry soil with its soil water content (SWC) was dissolved in $0.85 \% \mathrm{NaCl}$. Then, a $150 \mu \mathrm{L}$ aliquot of each sample was dispensed into each well of the microplates, and the microplates were incubated at $25^{\circ} \mathrm{C}$ for $240 \mathrm{~h}$; color development was measured by absorbance at $490 \mathrm{~nm}$ every $12 \mathrm{~h}$. Average Well Color Development (AWCD) was calculated with absorbance data as follows:

$$
\mathrm{AWCD}=\Sigma(C i-R) / 95 \text {, }
$$

where $C i$ is the absorbance data of each well except for the control well, and $R$ is the absorbance data of the control well.

\subsection{Statistical analysis}

A one-way ANOVA test for differences in soil properties and soil microbial community under different vegetation types was performed by SPSS17.0 (SPSS Institute Inc., 2002), and a LSD test was performed to carry out multiple post hoc comparisons.

The correlation analyses for altitude, vegetation types, soil properties and soil microbial characteristics were performed with the 'vegan' package [38] of the R-language environment (version 2.9, $\mathrm{R}$ Foundation for Statistical 
Computing, Vienna, Austria). To identify the individual influences of soil properties, vegetation types, and altitudinal variables, the unique and shared influences of the variables were disentangled using variation partitioning $[39,40]$. Partitioning was carried out through a series of partial redundancy analyses (pRDA).

The relationships among soil properties and soil microbial characteristics were analyzed by linear model redundancy analysis (RDA) using CANOCO software (Canoco for Windows 4.5). Data then underwent a logarithmic transformation before analysis; in RDA, significant environmental variables $(P<0.05)$ were selected using a forward selection followed by a Monte Carlo permutation test based on 999 random permutations [41]. The AWCD was analyzed by principal components analysis (PCA) using CANOCO.

\section{Results}

\subsection{Soil microbial community characteristics}

Soil microbial biomass was established as the total content of PLFAs in the soil microbial community (Figure 1), and it decreased as soil depth increased under all four vegetation types. The PLFA content under $\mathrm{L}$ was lower compared to that under $\mathrm{P}$ or BP at $0-5,5-10$ and $10-20 \mathrm{~cm}$. At $0-5 \mathrm{~cm}$ and $5-10 \mathrm{~cm}$, the total PLFA content under BP was the highest. However, the total PLFA content under P was highest at $10-20 \mathrm{~cm}$.

The fungal to bacterial biomass (F/B) ratio differed significantly $(P<0.05)$ among the four vegetation types (Figure $2 \mathrm{~A})$ and it showed a significant correlation with soil depth. At $0-5 \mathrm{~cm}$, the $\mathrm{F} / \mathrm{B}$ under all four vegetation types was lowest, and it increased significantly as depth increased to $5-10 \mathrm{~cm}$ and $10-20 \mathrm{~cm}$. This may indicate that the amount of fungi was higher at lower depths $(5-20 \mathrm{~cm})$ compared to that in the near-surface soil $(0-5 \mathrm{~cm})$. At $5-10 \mathrm{~cm}$, the F/B under $\mathrm{L}$ was discernibly higher than that under other vege-

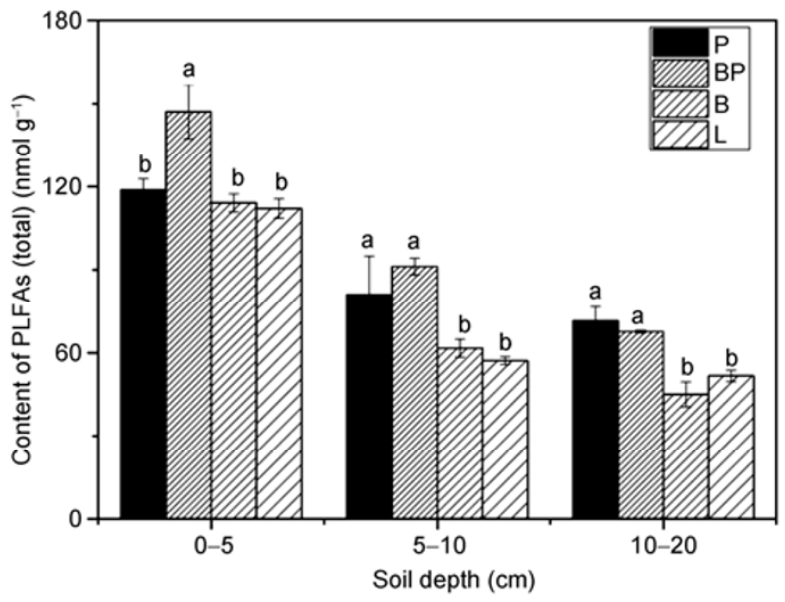

Figure 1 Comparison of PLFAs (total) among four vegetation types.

tation types but at 10-20 cm, the $\mathrm{F} / \mathrm{B}$ was highest under $\mathrm{B}$.

The MBC/MBN was also compared under the four vegetation types and different soil depths (Figure 2B). It was higher at 5-10 and $10-20 \mathrm{~cm}$ than at $0-5 \mathrm{~cm}$ among all vegetation types and was significantly higher under $L$ than under $\mathrm{P}, \mathrm{BP}$ and $\mathrm{B}$.

\subsection{The soil fungal community}

The soil fungal biomass (F) under the four vegetation types is shown in Figure 3. The $\mathrm{F}$ was positively correlated with soil depth $\left(r=0.518^{*}\right)$. At $5-10 \mathrm{~cm}$ and $10-20 \mathrm{~cm}$, the F of all four vegetation types was significantly higher than that at $0-5 \mathrm{~cm}$. At $0-5 \mathrm{~cm}$, $\mathrm{F}$ was highest under $\mathrm{L}$ and the $\mathrm{F}$ under $\mathrm{L}$ and $\mathrm{BP}$ was higher than that under $\mathrm{P}$ and $\mathrm{B}$ at both $0-5$ and $5-10 \mathrm{~cm}$.

The AWCD of the soil fungal community was compared using the absorbance data from the 96th hour (Figure 4) and it showed a significant negative correlation with soil depth $\left(r=-0.713^{* *}\right)$. It was also found that the AWCD values of
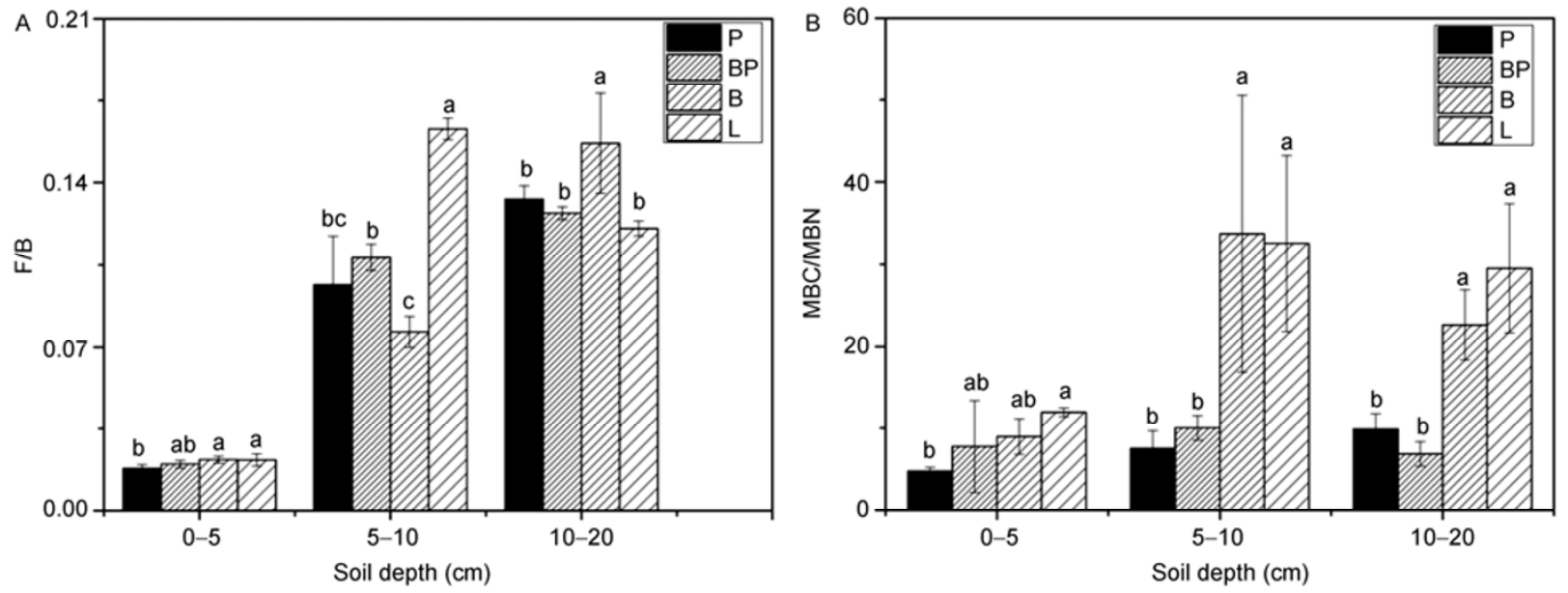

Figure 2 Comparison of fungal/bacterial biomass (A) and microbial biomass C/microbial biomass $\mathrm{N}$ (B) among four vegetation types. 


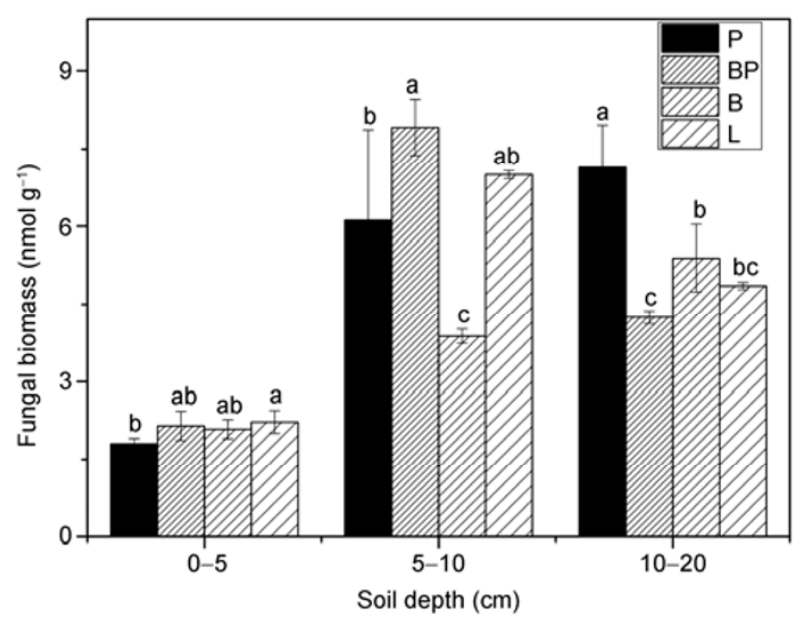

Figure 3 Comparison of fungal biomass among four vegetation types.

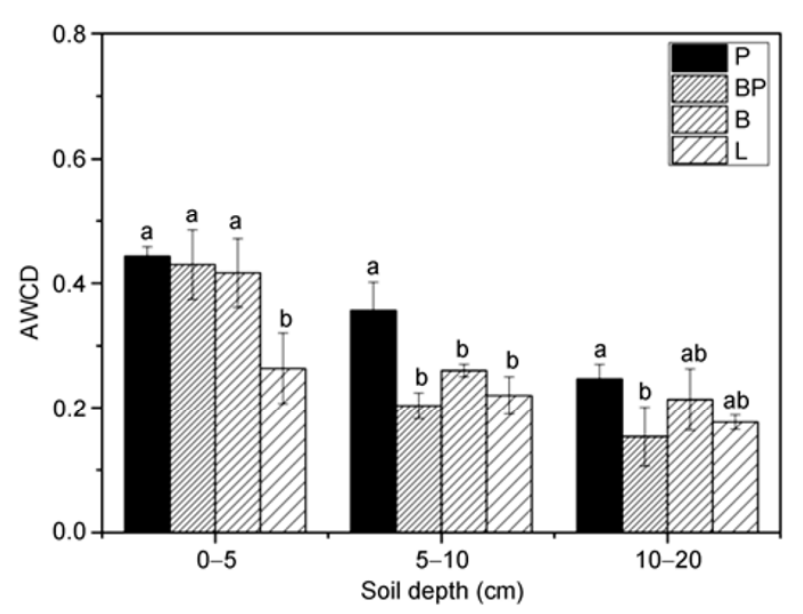

Figure 4 Comparison of average well color development (AWCD) among four vegetation types. broadleaf forests were significantly higher than those of conifer forests. The metabolic activity of soil under $\mathrm{P}$ was higher than that under BP or B at all three soil depths. At 0-5 cm, AWCD was lowest under L but the AWCD of BP was lower than that of $P$ and $B$ at $5-10 \mathrm{~cm}$ and $10-20 \mathrm{~cm}$.

Ninety-five kinds of $\mathrm{C}$ sources were sorted into six categories to show the differences in functional diversity of fungal community among the four vegetation types by the position of points in the PCA results (Figure 5). PC1 and PC2 accounted for $97.4 \%$ of total variance among $\mathrm{C}$ sources, thoroughly reflecting fungal community's utilization of the C sources. All six categories of C sources were distributed in the first and forth quadrants of the PCA results (Figure 5). Carbohydrates and miscellaneous, the only two sources found in the fourth quadrant, had loading scores that were higher on PC1 than those of amino acids, amines, carboxylic acids and polymers. Carbohydrates scored highest (0.988) in PC1, which proved that they were the most important $\mathrm{C}$ source for the fungal community.

Fungal community diversity produced different positions in the PCA results under different vegetation types, which indicated differences in the types and levels of $\mathrm{C}$ sources used and differences in their catabolic diversity. The PCA results usually differed at various depth levels, but they collected for certain vegetation types at certain depths. PCA results were different between all three soil depth levels under $\mathrm{L}$, indicating great variations in $\mathrm{C}$ source utilization. Under B and BP, the fungal diversities at $0-5$ and $5-10 \mathrm{~cm}$ were similar, but it varied at $10-20 \mathrm{~cm}$, which indicated that the level of $\mathrm{C}$ source utilization changed as soil depth increased. The $\mathrm{C}$ source utilization level of the fungal community was highest under P. Here, fungi at $0-5$ and 10-20 $\mathrm{cm}$ utilized more polymers, carbohydrate and miscellaneous, but fungi at $5-10 \mathrm{~cm}$ utilized more amino acids, carboxylic acids and amines. The $\mathrm{C}$ source utilization level under $\mathrm{B}$

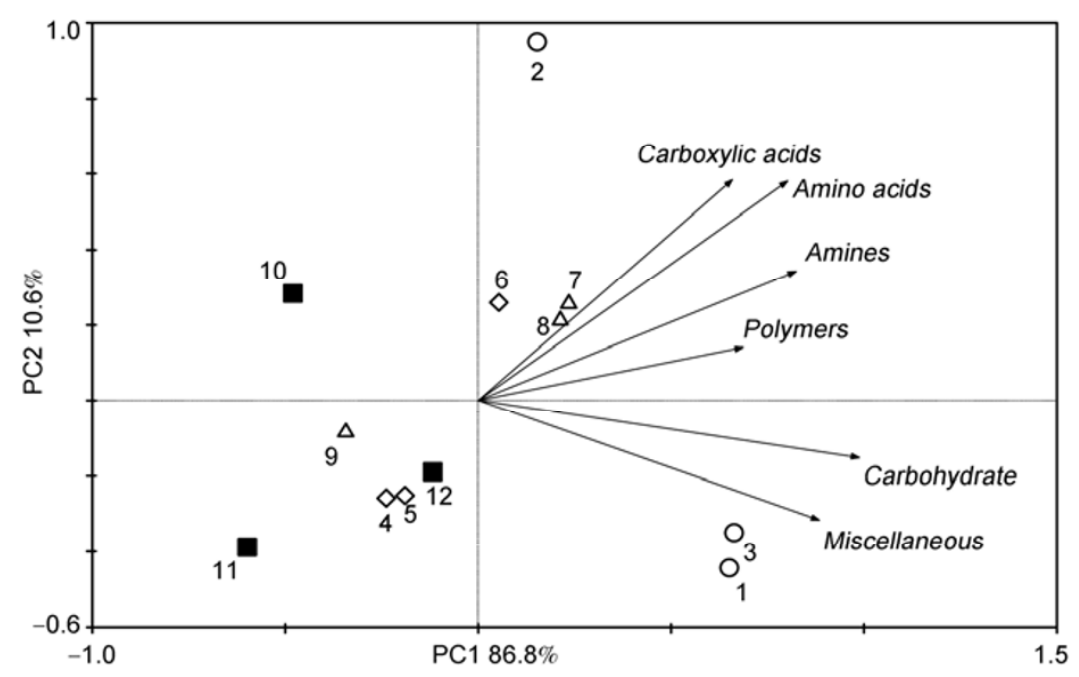

Figure 5 Principal components analysis (PCA) for soil fungi community diversity at four vegetation types. 1, P-5; 2, P-10; 3, P-20; 4, BP-5; 5, BP-10; 6, BP-20; 7, B-5; 8, B-10; 9, B-20; 10, L-5; 11, L-10; 12, L-20; -5, 0-5 cm; -10, 5-10 cm; -20, 10-20 cm. 
ranked second at $0-5$ and $5-10 \mathrm{~cm}$; here, fungi utilized more polymers, carboxylic acids, amines and amino acids. The $\mathrm{C}$ source utilization level under $\mathrm{L}$ at $0-5$ and $5-10 \mathrm{~cm}$ was lower compared to that of the other vegetation types.

\subsection{The relationships among soil microbial character- istics and environmental factors}

PC1 and PC2 explained $62.4 \%$ and $8.1 \%$ of total variance, respectively and their correlation coefficients with environmental factors were 0.948 and 0.737 , respectively (Figure 6). The soil properties that had significant effects on soil microbial community were total carbon (TC) $(P=0.002 * *$, $F=45.42)$, soil water content (SWC) $(P=0.002 * *, F=9.99)$, SOC/TN $(\mathrm{C} / \mathrm{N})(P=0.002 * *, F=5.81)$, and TC was the most important property among them.

Soil microbial biomass (PLFAs), baterial biomass (B) and AWCD were significantly positively correlated $(P<0.05)$ with TC, SWC and $\mathrm{C} / \mathrm{N}$. While $\mathrm{F} / \mathrm{B}, \mathrm{F}$ and $\mathrm{MBC} / \mathrm{MBN}$ were significantly negatively correlated with the three factors. Although Soil Organic Carbon (SOC) was not significantly correlated with $(P=0.316, F=1.2)$ microbial properties, it still has a considerable effect which could be distinguished from the length of the arrow and the intersection angles with microbial variables in Figure 6.

Because the study area encompassed multiple altitudinal gradients, the effects of altitude and vegetation were analyzed in addition to soil properties on the soil microbes. Results showed that soil properties explained $56 \%$ of microbial variance, while vegetation explained $12 \%$ and altitude explained $5 \%$ of microbial variance (Figure 7 ). The effects of soil properties and vegetation explained as much as $12 \%$ of soil microbial variance. Thus, soil properties had the greatest effect on soil microbe communities in the study. Because the effect of altitude on soil microbial community was insubstantial, its correlation with soil microbial community was not tested. The data revealed a high correlation with soil microbial community for SWC, SOC and TC, which was inconsistent with the results in Figure 6 in terms of SOC. The explanation of the variability of microbial properties for SOC turned to be significantly higher $(P<0.001)$ when the vegetation variable was included.

\section{Discussion}

\subsection{Responses of the soil microbial community to aboveground vegetation}

The total concentration of PLFAs in soil provides information on the soil microbial biomass [42], and the composition of signature components provides information on the microbial community structure $[34,35]$. The soil microbial biomass under $\mathrm{L}$ was low compared with that under $\mathrm{P}$ and $\mathrm{BP}$ at $0-5,5-10$ and $10-20 \mathrm{~cm}$. This indicated a smaller microbial source in conifer forest than in broadleaf forests, which was consistent with the fact that the SOC content under conifer was lower than that under broadleaf (Figure 8). The soil microbial biomass of mixed forests was higher than that of pure forests at the same soil depths (Figure 1). Saetre and Bååth [10] concluded that although tree species influenced soil moisture and understory vegetation, the effect of different types of vegetation on soil microbial community composition derived largely from the effect of vegetation on soil organic matter quality [11,43]. The data of soil organic matter (Figure 8) from this study supported this conclusion. Litter of mixed forests (BP) is more diverse than those of pure forests [44], thus requiring a larger variety of soil microbes for decomposition, which results in richer soil organic matter (especially in the 0-5 cm layer, Figure 8) and a higher soil microbial biomass (Figure 1).

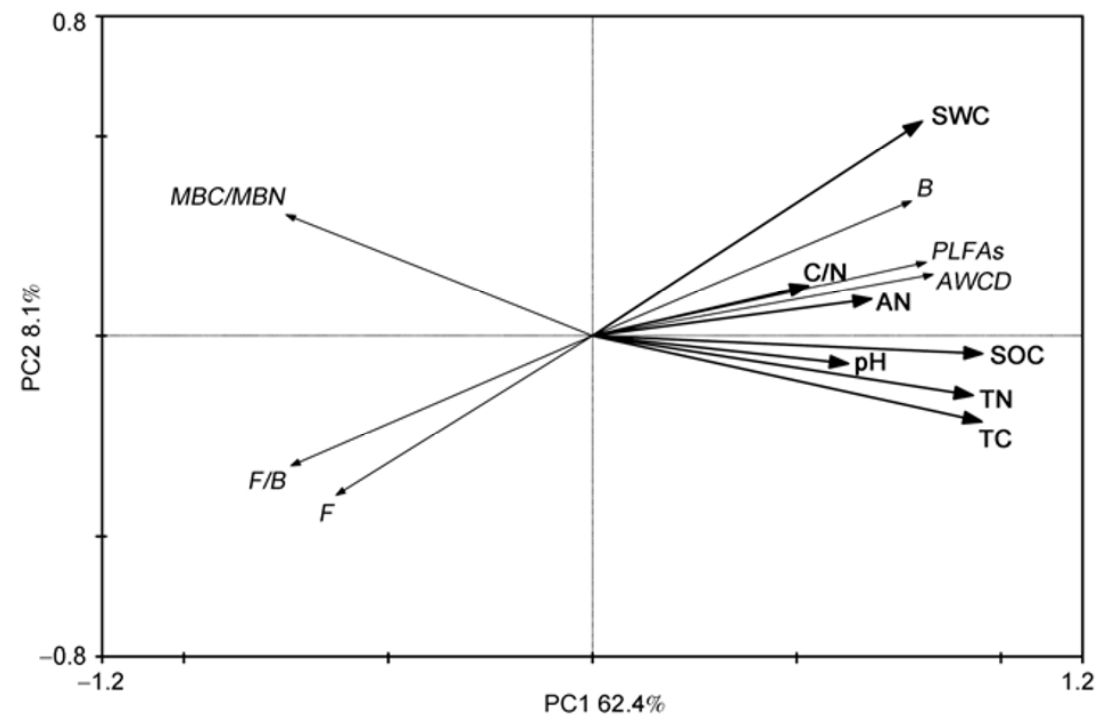

Figure 6 RDA analyses for soil chemical and physical properties and indexes of soil microbial community. 


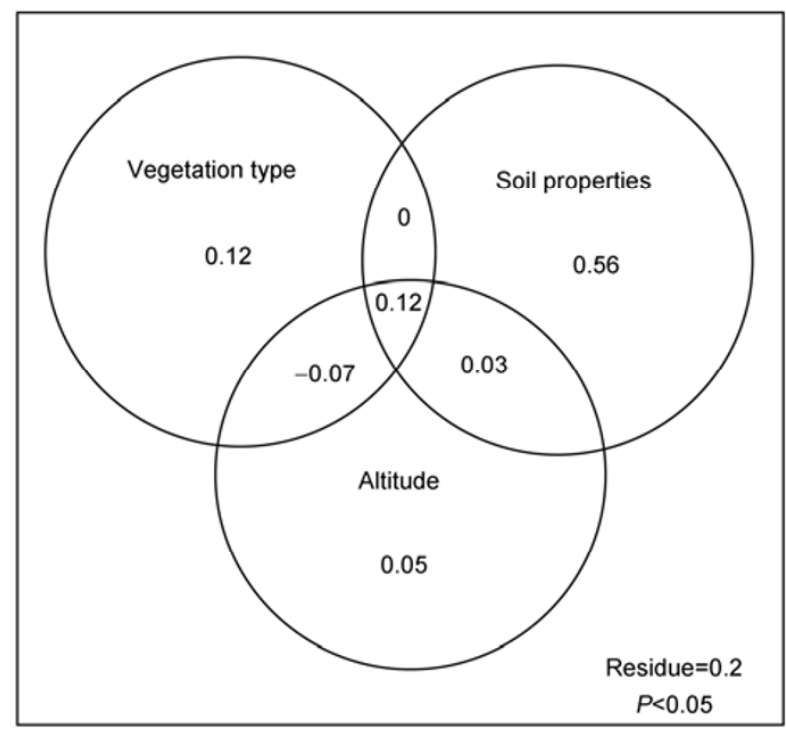

Figure 7 Variation partitioning of RDA analyses for vegetation type, soil properties and altitude.

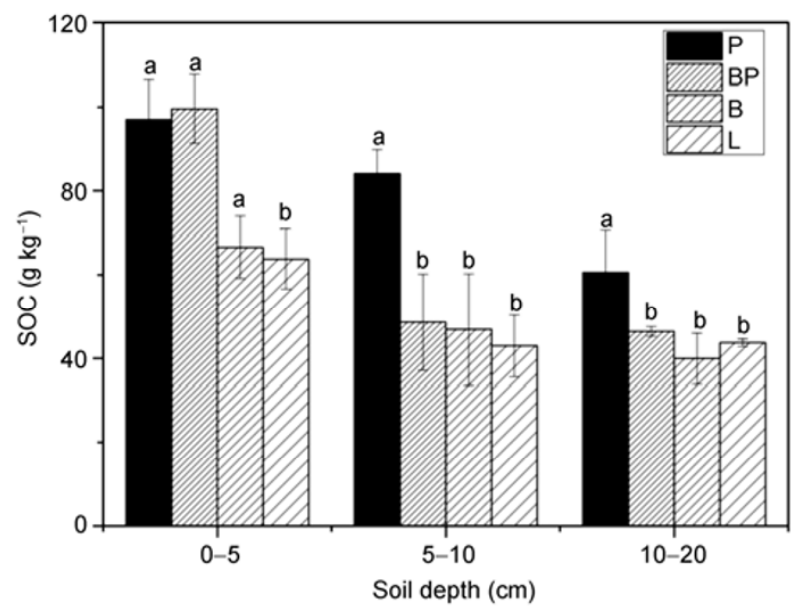

Figure 8 Comparison of soil organic carbon (SOC) among four vegetation types.

Merila et al. [12] suggested that SOC could act as the link between soil microbial community structure and vegetation composition as deciduous forest develops into boreal forest $[10,11]$. Because soil microbial biomass under other vegetation types (P, B and L) declined as SOC decreased (Figures 1 and 8), it was clear that soil organic matter quality had a direct influence on the soil microbial community [12]. Soil microbial biomass also declined with increasing soil depth (Figure 1), which was consistent with the results of a study by Kramer and Gleixner [45] on the corresponding variability of soil microbial biomass and soil organic matter (Figure 6).

Fungi and bacteria are the two main functional microbial components in soil [46], and F/B is generally used for representing microbial community structure [26]. At $0-5 \mathrm{~cm}$ and $5-10 \mathrm{~cm}$, the $\mathrm{F} / \mathrm{B}$ under $\mathrm{L}$ was notably higher than that of other vegetation types (Figure 2A). This was also clear in the results of MBC/MBN (Figure 2B). Vegetation transfers substrates of varying quality to microbes through litterfall. Deciduous litterfall provides high quality and quantity substrates, leading to propagation of bacteria, which favor high-nutrient soil. Fungi, on the other hand, favor soil with low fertility or with more phenols and difficult-todecompose organic matter [50]. Therefore, the prevalence of fungi grows as vegetation shifts from deciduous to conifer. The F/Bs under all four vegetation types were significantly higher at $5-10$ and $10-20 \mathrm{~cm}$ than to those at $0-5 \mathrm{~cm}$. The MBC/MBN under $\mathrm{B}$ and $\mathrm{L}$ also produced this trend, which indicated that the fungal ratio in soil microbial community was high at $5-20 \mathrm{~cm}$ compared to that in the near-surface mineral soil $(0-5 \mathrm{~cm})$. This was consistent with the results of $\mathrm{MBC} / \mathrm{MBN}$ under trembling aspen, paper birch and mixed coniferous forests [47]. The MBC/MBN was found to be more significantly correlated with TC than with SOC, while the F/B was more obviously correlated with SOC (Figure 6). The F/B at different soil layers also corresponded to the variation of SOC with soil depth, especially regarding the large difference in $\mathrm{F} / \mathrm{B}$ between $0-5 \mathrm{~cm}$ and $5-10 \mathrm{~cm}$ (Figure 2A). The effect of vegetation on soil microbial community composition derived from the effect of vegetation on soil organic matter quality [11]. Thus, F/B may more accurately reflect the variability of soil microbial community structure than MBC/MBN.

\subsection{The response of the fungal community catabolic diversity to vegetation types}

The AWCD represents fungal community utilization of C sources and was AWCD highest under $\mathrm{P}$, and lowest under L (Figure 4). This inconsistency of fungal biomass and fungal catabolic activity under $\mathrm{L}$ was probably because the fungal community composition under $\mathrm{L}$ was relatively similar so that there were not enough kinds of fungi to utilize the various $C$ sources. As Ponge [48] found that succession of fungi happened during decomposition of pine needles, not all fungi existed at one individual phase of decomposition. Therefore, fungal biomass was not always consistent with fungi diversity. The results indicated that the utilization level and diversity of $\mathrm{C}$ sources were higher under broadleaf than under conifer (Figure 5). The variability of AWCD was obviously positively correlated with SOC (Figure 6), which demonstrated that the soil metabolic diversity was determined by SOC to a great extent. Broadleaf and conifer vegetation had different effects on soil quality [43]. For example, the nutrient turnover rate was higher in broadleaf forests than it was in conifer forests, resulting in higher nutrients levels under broadleaf [27,49]. Available nutrients in soil depleted as vegetation developed from 
broadleaf into conifer [12], and difficult-to-decompose alkyl-C material and phenols accumulated in soil organic matter [50]. The AWCD under all types of vegetation declined with increases in soil depth, and was particularly evident at $0-10 \mathrm{~cm}$. This may also relate to the decreasing levels of SOC as soil depth increases.

Fungal biomass significantly increased with soil depth (Figure 3), and similar to AWCD, it was apparently correlated with the variability of SWC and SOC (Figure 6). Since the sampling occurred in the hottest month, and the variance of soil temperature was very small (data not shown), the effect of soil temperature on the soil microbial community was excluded. However, the soil water condition contributed to the variances of fungal community and catabolic diversity.

\subsection{The relationships of vegetation types, soil proper- ties, and altitude with soil microbial characteristics}

The soil microbial communities in this study were influenced by soil, vegetation, and altitude. RDA analysis showed that soil properties were the most influential of the three factors on the soil microbial communities, followed by vegetation type. The altitude had a very weak effect on soil microbial communities (Figure 7).

RDA (Figure 6) indicated that SWC was the most important factor affecting soil microbial community structures. The negative correlation between SWC and fungal biomass was more evident at $0-5 \mathrm{~cm}$ than at 5-10 and $10-20 \mathrm{~cm}$. The elevation of SWC increased bacterial biomass [51] while weakening fungal biomass [20]. Needles decompose slowly, leading to a thicker humus layers under conifer vegetation than broadleaf, which may have been a barrier to precipitation into soil and eventually lowered SWC in topsoil under conifer [52,53].

The negative correlation of soil available nutrients and $\mathrm{pH}$ with F/B may be due to different living habits of bacteria and fungi (Figure 6). The negative correlation between $\mathrm{pH}$ and $\mathrm{F} / \mathrm{B}$ was confirmed in multiple comparison studies that determined that soil with low $\mathrm{pH}$ promotes fungi and restrains bacteria $[18,24,46,54]$. Fungi prefer to live in acidic soil with low available nutrients and high contents of difficult-to-decompose organic matter [28], while bacteria favor soil with abundant nutrients that are highly decomposable $[25,55]$. Some studies found a positive correlation between $\mathrm{C} / \mathrm{N}$ and F/B [12,24]. However, $\mathrm{C} / \mathrm{N}$ had a negative correlation with $\mathrm{F} / \mathrm{B}$ in the present results. This was probably because more deciduous forests ( $\mathrm{P}, \mathrm{BP}$ and $\mathrm{B}$ ) were distributed in the area, which led to a higher content of soil available $\mathrm{C}$. Therefore, high $\mathrm{C} / \mathrm{N}$ favored bacteria and did not lead to a correspondingly high F/B. Because the effect of $\mathrm{C} / \mathrm{N}$ was relatively weak and the variance explained by $\mathrm{C} / \mathrm{N}$ was lower than SOC, TC and SWC (Table 2), it was considered that $\mathrm{C} / \mathrm{N}$ may be not as effective as these in presenting the effects of types of vegetation on soil microbial community.

In summary, in a study of the effects of four vegetation types on soil microbial properties, it was found that soil properties, especially soil organic carbon and soil water content, contributed significantly to variations in soil microbial biomass, composition and fungal catabolic diversity. The soil microbial biomass, fungal biomass, and fungal catabolic ability significantly declined with soil depth. However, the ratio of fungi to bacteria increased with soil depth. The fungi ratio also increased as vegetation developed from broadleaf to conifer, although the soil microbial biomass was lower under larch compared to poplar, birch and their mixed forests. As a representation of microbial community structure, F/B may be more sensitive to vegetation than MBC/MBN. The direct contribution of vegetation types to soil microbial community was $12 \%$. If the indirect effect through soil organic carbon is considered, the variation in vegetation types could have substantial consequences for soil microbial composition and diversity. These results indicate that overarching ecological factors, such as soil organic carbon, are important influences on the soil microbial community in this boreal forest ecosystem, in terms of both biomass and community composition, and they have implications for ecosystem rehabilitation and conservation in Northeast China.

Table 2 Results of RDA analyses for vegetation types, soil chemical and physical properties and indexes of soil microbial community characteristics

\begin{tabular}{|c|c|c|c|c|c|}
\hline Dependent variable & Independent variable & $\begin{array}{l}\text { Explained } \\
\text { variance }\end{array}$ & Significance & $\begin{array}{c}\text { Explained variance } \\
\text { without } \\
\text { altitude } \\
\end{array}$ & Significance \\
\hline \multirow[t]{7}{*}{ Microbial properties } & Vegetation types & 0.17 & $<0.001$ & 0.12 & $<0.001$ \\
\hline & $\mathrm{pH}$ & 0.203 & $<0.001$ & 0.11435 & $<0.001$ \\
\hline & SOC & 0.49479 & $<0.001$ & 0.35423 & $<0.001$ \\
\hline & $\mathrm{TC}$ & 0.4996 & $<0.001$ & 0.34453 & $<0.001$ \\
\hline & $\mathrm{AN}$ & 0.24808 & $<0.001$ & 0.17933 & $<0.001$ \\
\hline & $\mathrm{C} / \mathrm{N}$ & 0.15369 & $<0.001$ & 0.08381 & 0.02 \\
\hline & SWC & 0.4227 & $<0.001$ & 0.41696 & $<0.001$ \\
\hline
\end{tabular}


This work was supported by the National Natural Science Foundation of China (30700639, 31170581).

1 Bardgett R D, Wardle D A. Aboveground-belowground Linkages: Biotic Interactions, Ecosystem Processes, and Global Change. New York: Oxford University Press, 2010

2 Zak D R, Holmes W E, White D C, et al. Plant diversity, soil microbial communities, and ecosystem function: are there any links? Ecology, 2003, 84: 2042-2050

3 Wagg C, Husband B C, Green D S, et al. Soil microbial communities from an elevational cline differ in their effect on conifer seedling growth. Plant Soil, 2011, 340: 491-504

4 Broughton L C, Gross K L. Patterns of diversity in plant and soil microbial communities along a productivity gradient in a Michigan old-field. Oecologia, 2000, 125: 420-427

5 Maly S, Korthals G W, Van Dijk C, et al. Effect of vegetation manipulation of abandoned arable land on soil microbial properties. Biol Fert Soils, 2000, 31: 121-127

6 Carney K M, Matson P A. Plant communities, soil microorganisms, and soil carbon cycling: does altering the world belowground matter to ecosystem functioning? Ecosystems, 2005, 8: 928-940

7 Eviner V T. Plant traits that influence ecosystem processes vary independently among species. Ecology, 2004, 85: 2215-2229

8 De Deyn G B, Cornelissen J H C, Bardgett R D. Plant functional traits and soil carbon sequestration in contrasting biomes. Ecol Lett, 2008, 11: 516-531

9 Hobbie S E, Ogdahl M, Chorover J, et al. Tree species effects on soil organic matter dynamics: the role of soil cation composition. Ecosystems, 2007, 10: 999-1018

10 Saetre P, Baath E. Spatial variation and patterns of soil microbial community structure in a mixed spruce-birch stand. Soil Biol Biochem, 2000, 32: 909-917

11 Tscherko D, Hammesfahr U, Zeltner G, et al. Plant succession and rhizosphere microbial communities in a recently deglaciated alpine terrain. Basic Appl Ecol, 2005, 6: 367-383

12 Merila P, Malmivaara-Lamsa M, Spetz P, et al. Soil organic matter quality as a link between microbial community structure and vegetation composition along a successional gradient in a boreal forest. Appl Soil Ecol, 2010, 46: 259-267

13 Aneja M K, Sharma S, Fleischmann F, et al. Microbial colonization of beech and spruce litter -influence of decomposition site and plant litter species on the diversity of microbial community. Microbial Ecol, 2006, 52: 127-135

14 Kazakou E, Vile D, Shipley B, et al. Co-variations in litter decomposition, leaf traits and plant growth in species from a Mediterranean old-field succession. Funct Ecol, 2006, 20: 21-30

15 Zak D R, Tilman D, Parmenter R R, et al. Plant-production and soil-microorganisms in late-successional ecosystems-a continental-scale study. Ecology, 1994, 75: 2333-2347

16 Mitchell R J, Hester A J, Campbell C D, et al. Explaining the variation in the soil microbial community: do vegetation composition and soil chemistry explain the same or different parts of the microbial variation? Plant Soil, 2012, 351: 355-362

17 Wardle D A, Yeates G W, Nicholson K S, et al. Response of soil microbial biomass dynamics, activity and plant litter decomposition to agricultural intensification over a seven-year period. Soil Biol Biochem, 1999, 31: 1707-1720

18 Bååth E, Anderson T H. Comparison of soil fungal/bacterial ratios in a $\mathrm{pH}$ gradient using physiological and PLFA-based techniques. Soil Biol Biochem, 2003, 35: 955-963

19 Fierer N, Strickland M S, Liptzin D, et al. Global patterns in belowground communities. Ecol Lett, 2009, 12: 1238-1249

20 Staddon W J, Trevors J T, Duchesne L C, et al. Soil microbial diversity and community structure across a climatic gradient in western Canada. Biodivers Conserv, 1998, 7: 1081-1092

21 Carletti P, Vendramin E, Pizzeghello D, et al. Soil humic compounds and microbial communities in six spruce forests as function of parent material, slope aspect and stand age. Plant Soil, 2009, 315: 47-65

22 Rogers B F, Tate R L. Temporal analysis of the soil microbial community along a toposequence in Pineland soils. Soil Biol Biochem, 2001, 33: 1389-1401

23 White C, Tardif J C, Adkins A, et al. Functional diversity of microbial communities in the mixed boreal plain forest of central Canada. Soil Biol Biochem, 2005, 37: 1359-1372

24 Merila P, Strommer R, Fritze H. Soil microbial activity and community structure along a primary succession transect on the land-uplift coast in western Finland. Soil Biol Biochem, 2002, 34: 1647-1654

25 Hogberg M N, Baath E, Nordgren A, et al. Contrasting effects of nitrogen availability on plant carbon supply to mycorrhizal fungi and saprotrophs - a hypothesis based on field observations in boreal forest. New Phytol, 2003, 160: 225-238

26 Frostegård A, Bååth E. The use of phospholipid fatty acid analysis to estimate bacterial and fungal biomass in soil. Biol and Fert Soils, 1996, 22: 59-65

27 Ulery A L, Graham R C, Chadwick O A, et al. Decade-scale changes of soil carbon, nitrogen and exchangeable cations under chaparral and pine. Geoderma, 1995, 65: 121-134

28 Taylor D L, Herriott I C, Stone K E, et al. Structure and resilience of fungal communities in Alaskan boreal forest soils. Can J Forest Res, 2010, 40: 1288-1301

29 Vance E D, Brookes P C, Jenkinson D S. An extraction method for measuring soil microbial biomass C. Soil Biol Biochem, 1987, 19: 703-707

30 Wu J, Joergensen R G, Pommerening B, et al. Measurement of soil microbial biomass $\mathrm{C}$ by fumigation extraction-an automated procedure. Soil Biol Biochem, 1990, 22: 1167-1169

31 Brookes P C, Kragt J F, Powlson D S, et al. Chloroform fumigation and the release of soil-nitrogen - the effects of fumigation time and temperature. Soil Biol Biochem, 1985, 17: 831-835

32 Bligh E G, Dyer W J. Orange-red flesh in cod and haddock. J Fish Res Board Canada, 1959, 16: 449-452

33 Frostegård J, Haegerstrand A, Gidlund M, et al. Biologically modified LDL increases the adhesive properties of endothelial-cells. Atherosclerosis, 1991, 90: 119-126

34 Frostegård A, Bååth E, Tunlid A. Shifts in the structure of soil microbial communities in limed forests as revealed by phospholipid fatty-acid analysis. Soil Biol Biochem, 1993, 25: 723-730

35 Frostegård A, Tunlid A, Bååth E. Phospholipid fatty-acid composition, biomass, and activity of microbial communities from 2 soil types experimentally exposed to different heavy-metals. Appl Environ Microb, 1993, 59: 3605-3617

36 Bååth E. The use of neutral lipid fatty acids to indicate the physiological conditions of soil fungi. Microbial Ecol, 2003, 45: 373-383

37 Singh M P. Application of Biolog Ff MicroPlate for substrate utilization and metabolite profiling of closely related fungi. J Microbiol Meth, 2009, 77: 102-108

38 Dixon P. Vegan, a package of R functions for community ecology. J Veg Sci, 2003, 14: 927-930

39 Borcard D, Legendre P, Drapeau P. Partialling out the spatial component of ecological variation. Ecology, 1992, 73: 1045-1055

40 Okland R H. Partitioning the variation in a plot-by-species data matrix that is related to $n$ sets of explanatory variables. J Veg Sci, 2003, 14: 693-700

41 Manly B F J. Randomization, Bootstrap and Monte Carlo Methods in Biology. London: Chapman \& Hall/CRC, 2006

42 Frostegård A, Tunlid A, Bååth E. Microbial biomass measured as total lipid phosphate in soils of different organic content. J Microbiol Meth, 1991, 14: 151-163

43 Saetre P. Spatial patterns of ground vegetation, soil microbial biomass and activity in a mixed spruce-birch stand. Ecography, 1999, 22: 183-192

44 Fontaine S, Mariotti A, Abbadie L. The priming effect of organic matter: a question of microbial competition? Soil Biol Biochem, 2003, 35: 837-843

45 Kramer C, Gleixner G. Soil organic matter in soil depth profiles: dis- 
tinct carbon preferences of microbial groups during carbon transformation. Soil Biol Biochem, 2008, 40: 425-433

46 Joergensen R G, Wichern F. Quantitative assessment of the fungal contribution to microbial tissue in soil. Soil Biol Biochem, 2008, 40: 2977-2991

47 Bauhus J, Pare D, Cote L. Effects of tree species, stand age and soil type on soil microbial biomass and its activity in a southern boreal forest. Soil Biol Biochem, 1998, 30: 1077-1089

48 Ponge J F. Succession of fungi and fauna during decomposition of needles in a small area of Scots pine litter. Plant Soil, 1991, 138: 99-113

49 Quideau S A, Chadwick O A, Graham R C, et al. Base cation biogeochemistry and weathering under oak and pine: a controlled long-term experiment. Biogeochemistry, 1996, 35: 377-398

50 Wardle D A, Nilsson M C, Zackrisson O, et al. Determinants of litter mixing effects in a Swedish boreal forest. Soil Biol Biochem, 2003,
35: 827-835

51 Myers R T, Zak D R, White D C, et al. Landscape-level patterns of microbial community composition and substrate use in upland forest ecosystems. Soil Sci Soc Am J, 2001, 65: 359-367

52 Rey A, Pegoraro E, Jarvis P G. Carbon mineralization rates at different soil depths across a network of European forest sites (forcast). Eur J Soil Sci, 2008, 59: 1049-1062

53 Jiang Y M, Chen C R, Liu Y Q, et al. Soil soluble organic carbon and nitrogen pools under mono- and mixed species forest ecosystems in subtropical china. J Soil Sediment, 2010, 10: 1071-1081

54 Bailey V L, Smith J L, Bolton H. Fungal-to-bacterial ratios in soils investigated for enhanced C sequestration. Soil Biol Biochem, 2002, 34: $997-1007$

55 Ingwersen J, Poll C, Streck T, et al. Micro-scale modelling of carbon turnover driven by microbial succession at a biogeochemical interface. Soil Biol Biochem, 2008, 40: 864-878

Open Access This article is distributed under the terms of the Creative Commons Attribution License which permits any use, distribution, and reproduction in any medium, provided the original author(s) and source are credited. 